\title{
新旧动能转换背景下财政支持促进装备制造业转型升级了吗? 一以山东济南为例
}

齐菁华

山东财经大学

DOI:10.32629/ej.v3i2.436

[摘 要] 新旧动能转换,是指通过引入新动能以及改造旧动能等逐步替换旧动能,解决旧动能无法满足企业发展和创新转型升级问题的措施。 新动能一般是指新技术、新产业、新业态、新模式等。自2017年起,新旧动能转换重大工程就倍受关注,次年初,济南市召开了有关新旧动能转 换工程的动员大会,并提出了一系列财税优惠政策。本文以山东省济南市为例,基于PEST模型,分析新旧动能转换背景下,财税政策支持对装备制 造业转型升级的作用研究,并提出通过加大财税支持力度、扩大融资途径、组织技能培训等手段和方法,促进装备制造业转型升级的政策建议。 [关键词] 新旧动能转换; 制造业; 转型升级

\section{1 当前发展现状}

山东省是我国第一个以新旧动能为主题的试验区, 这也是山东省经济 发展的一大良机, 相关部门对此问题十分重视, 试验区以济南、青岛、烟台 三市为重点区域, 并联合其他地级市, 最终确定了 “三核引领、多点突破、 融合互动” 的布局。

而制造业作为国民经济发展的重要部门, 关系到国家核心竞争力, 山东省是制造业大省, 目前居全国前列。但与发达国家以及国内其他省 市相比, 还存在关键技术开发能力不强, 高技术人才不足等短板, 故在新 旧动能背景下, 如何利用财税政策支持装备制造业的发展是一个值得研 究的问题。

\section{2 研究目的}

通过探究济南市装备制造业发展现状, 及时反馈新旧动能总体方案在 设计和执行过程中存在的问题, 进而提出合理性建议, 同时结合发达国家 及国内其他制造业发展迅速的城市的经验, 发现当下财税制度的不足, 不 断创新和完善财税制度。本文的研究成果不仅为山东省提供了装备制造业 转型升级的理论依据, 同时也在政策设计、效率提升和政策优化等方面具 有借鉴意义。

\section{3 研究方法}

本文采用PEST模型对济南市制造业的发展环境进行分析, PEST分析是 指宏观环境的分析, 宏观环境又称一般环境, 是指影响一切行业和企业的 各种宏观力量。对宏观环境因素作分析, 不同行业和企业根据自身特点和 经营需要, 分析的具体内容会有差异, 但一般都应对政治 (Political)、经 济 (Economic)、技术 (Technological) 和社会 (Social) 这四大类影响企业 的主要外部环境因素进行分析。

\section{4 基于 PEST 模型对济南地区装备制造业发展的分析}

在历史上, 济南曾是重要的制造业基地, 但是近几年来看, 和沿海地区 相比, 济南的发展有些缓慢, 为重振济南制造业的发展, 目前已确立了工业 强市的思想, 要加大力发展济南的装备制造业, 明确济南装备制造业发展 的优势和长处, 充分发挥本市的特长, 如此, 才能提高济南制造业在国内外 市场的竞争力, 因而济南装备制造业竞争力的提升和如何支持装备制造业 的发展成为当下函待解决的问题。

其中, 财政支持是促进济南装备制造业发展的重要手段和措施, 首先 对于初入市场的制造业企业来说, 有大量的研究开发费用, 为保证新进企 业的存活率, 必要的财政支持可以促进企业尽快达到盈亏平衡点。而对于 成立不久的小微型企业, 其面临的是较为成熟的市场和强大的竞争力对手,
有力的财政补贴可以帮助小微企业降低成本, 提升利润空间, 增强其面 对风险的承受力和抵抗力。同时, 对于处于夕阳阶段的企业来说, 财政补 贴可以延缓其退出市场的时间, 也能帮助面临收支不平衡困难的企业渡 过难关。

再者, 从装备制造业的持续发展的角度来看, 政府利用财政税收政策 进行有效的配置资源, 通过减税免税等优惠措施切实降低企业税负, 增强 企业在全行业中的竞争力; 同时, 政府也可以对企业提供在管理方面的指 导等, 提高企业的行政效率。

基于上述理论, 本文将利用PEST模型对济南制造业面临的外部环境进 行分析。

4.1 社会环境分析

随着政府宣传力度的增加, 全社会对装备制造业的支持和重视程度逐 步提高, 为进一步加快新旧动能的转换, 做好 “双招双引”, 近几年来, 济南 涌现出一大批以新旧动能转换为依托的各种社会组织, 各种比赛、交流活 动和会议等陆续展开。我省高校也在2018年开始实施高级技能名师访学计 划, 并投入了 260 万的财政补助资金, 同时, 借助各技工院校, 大力开展职能 培训活动, 提升高技能人才的专业技术素养。

4.2经济环境分析

4.2.1落实积极的财政政策稳定经济增长

少索取多给予, 在企业发展困难的时候, 及时减轻企业的负担, 不断增 强实体经济的生存活力, 同时顺应提高财政收入质量的目标, 适时根据情 况调整财政收入目标。

增加有效财政投入, 把扩大有效投入作为稳定实体经济发展的重要手 段, 大力支持全市重点项目的建设, 增加财政支持力度, 缓解经济发展下行 压力, 一方面, 要加强融资平台的建设和管理, 扩大资金筹集的广度和深度, 确保重点项目的顺利实施; 另一方面, 要同时抓好经济发展和扶持民生, 在更宽的领域支持利民惠民工程的建设; 其次, 要加大政府采购力度, 扩大 采购范围, 拉动全社会需求总量。最后, 引导民间资本, 增强企业发展活力, 民营企业作为实体经济的主体, 在强化财政政策上发挥着关键作用, 要鼓 励和引导民间资本的投入。

4.2.2财政金融深度融合倍增支持效率

适度扩大信贷总量, 引导银行等其他金融机构增加信贷投放规模, 支 持科技金融, 特别是针对广大中小企业抵押品少的现状, 要立足减轻和分 散风险, 出台一系列促进资本和技术相结合的政策, 并创造覆盖科技企业 成长全过程的融资服务体系。 


\title{
市场经济下中小企业人力资源管理的分析
}

\author{
周灵芝
}

广东坚朗五金制品股份有限公司

DOI:10.32629/ej.v3i2.417

[ 摘 要] 中小企业是市场经济的主要组成部分, 其对经济的发展、社会的进步都发挥着至关重要的作用。现如今, 中小企业正处于发展的关键 阶段, 中小企业要想提高经营管理效率,应首先做好人力资源管理工作了解当前人力资源管理现状,总结常见管理问题。人力资源管理在优化企 业资源配置、保障企业人力资源供给、促进企业发展方面起着不可忽视的作用。本文对于中小企业人力资源管理现状与对策进行了分析, 希望 为以后的具体工作起到实际的参考作用。

[关键词] 中小企业; 人力资源管理；对策

\section{1 中小企业人力资源管理特点概述}

1. 1 中小企业对于企业员工的综合素质要求相对较高

中小企业相比于大型企业来说, 由于企业的规模有限, 企业的员工成 本投入有限, 因此员工数量整体来说相对较少, 有的岗位甚至需要一人兼 任多职, 特别是管理人员数量控制更加严格, 因此中小企业在人力资源管 理方面要求企业员工应该具有较强的应变沟通能力、实际操作能力以及一 定的组织协调能力。

\section{2中小企业在人力资源管理方面更加灵活}

中小企业相比于大中型企业来说, 企业员工无论是在工作时间的安排 上还是工作岗位设置上, 都更加方便灵活, 可以根据企业的生产经营实际 状况随时进行调整, 而且企业的管理层以及人力资源管理部门在用人上更 加自由灵活, 可以采取多种方式充实员工队伍力量。

1. 3中小企业更容易全面掌握企业员工情况

中小企业由于规模较小, 人员较少, 因此在人力资源管理过程中, 更 能准确全面的掌握企业员工的实际情况, 也更有利于加强企业人力资源 管理部门和员工之间的沟通联系, 对于调动企业员工的积极性和创造性

\section{3政治环境分析}

2017 年, 济南市正式确立实施新旧动能转换重大工程, 各级有关部 门主动响应号召, 陆续出台 100 多项政策措施, 同时启动一批重点建设项 目。可见, 新旧动能转换已成为我省工作的重中之重, 在新旧动能转换背 景下, 财政支持装备制造业的发展的作用尤为突出。

与经济变化相辅相成的, 是政治领域的税务改革。2018年, 陆续出台了 很多针对制造业的税收政策, 这些政治手段将会辅佐经济手段, 进一步促 进装备制造业的转型升级。

\section{4技术环境分析}

对企业的发展, 除了有财政的支持外, 还需要有技术的支撑, 立足创新 驱动发展战略, 打造制造业高水平创新平台, 利用技术创新提升行动。建设 创业辅导基地和创业创新学院, 加快创新成果向新专利、新产品的转化。

\section{5 结论和政策建议}

基于上述分析, 本文得出以下结论和政策建议, 对于济南制造业的重 振, 财税的支持不可或缺, 要做好必要的前期准备, 给制造业的发展提供有 力的财税环境。而且要坚持 “减税降费”, 切实降低企业的税收负担, 缓解 其面临的发展困境, 即以财政收入的减少换取其对制造业发展和经济增长 的乘数效应。

同时, 政府可以通过制定合理有效的方案, 如组织技术竞赛, 安排技师 出国访学等提高从业人员的技术素质; 另外, 通过扩大政府采购, 有效拉动
非常有利。

\section{2 中小企业人力资源管理必要性}

2. 1 原因

目前, 我国多数中小企业以实现短期经济效益为目标, 受这一发展目 标影响, 中小企业发展规划以及发展方案制定会受到直接影响, 多数中小 企业不注重人力资源管理工作, 此项工作得到的资金支持、技术支持较少。 再加上, 中小企业发展时间较短, 经营管理经验不足, 未能根据市场动态变 化情况及时调整发展战略, 并且人力资源管理十分混乱, 长此以往, 企业员 工会产生离职想法, 人力资源管理效果达不到预期要求。为了改变中小企 业在人力资源管理方面的现状, 务必制定切实可行的人力资源管理策略, 从中能够看出, 加强中小企业人力资源管理是极为必要的。

2. 2 意义

强化人力资源管理, 结合中小企业实际情况制定人力资源管理策略, 能够大大提高管理效率, 确保人力资源合理配置, 避免人力资源浪费。与此 同时, 有利于树立一致的企业发展目标, 增强企业员工凝聚力, 这对中小企 业有序管理有重要意义。中小企业人力资源管理效果优化, 能为员工营造

社会内需, 扩大消费。

[参考文献]

[1]省政协常委侯风云.新旧动能转换下的金融风险化解与防范 $[N]$. 联 合日报,2018.

[2]董燕. 交通运输对新旧动能转换重大工程的作用[J]. 山东交通科 技,2018,(03):6-8+30.

[3]尚小琳.科技金融助力山东省新旧动能转换智慧产业化 [J].金融经 济,2018,(12):156-157.

[4]王本东,朱晓静.基于新旧动能转换的山东中小企业发展研究[J].山 东行政学院学报,2018,(03):115-119+128.

[5]孙丽文,米慧欣,李少帅. 创新驱动新旧动能转换的作用机制研究 [J]. 河北工业大学学报(社会科学版),2019,11(01):22-28+49.

[6]韩羽.加快新旧动能转换 推动传统产业转型升级一山东省食品 工业协会第八次会员代表大会暨产学研合作推动工业转型升级高峰论坛 在济南召开[J].中国科技产业,2017,(09):50-51.

[7]赵丽娜. 产业转型升级与新旧动能有序转换研究——以山东省为 例[J].理论学刊,2017,(02):68-74.

作者简介:

齐菁华(1998--), 女, 汉族, 山东济南人, 本科生, 研究方向：财税 政策。 